TAPROBANICA, ISSN 1800-427X. December, 2013. Vol. 05, No. 02: pp. 144-147, 1 pl.

(C) Taprobanica Private Limited, 146, Kendalanda, Homagama, Sri Lanka.

http://www.sljol.info/index.php/tapro

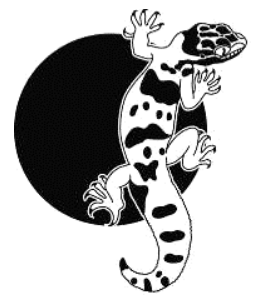

\section{Taxonomic notes on two Jasminum species (Oleaceae) from India}

During systematic studies of Jasminum L. in Kerala, the authors collected a curious species from the wild as well as from cultivation. Critical study based on relevant literature and type material allowed us to identify the plant as $J$. azoricum L. Consultation of other regional herbaria in India revealed that several similar specimens were erroneously determined as $J$. flexile and many sheets of $J$. flexile were identified as $J$. azoricum. Searching the literature and other regional floras showed considerable confusion about the identity of these two species in India.

Jasminum azoricum was proposed by Carl Linnaeus in 1753. He inadvertently cited its habitat as India in Species Plantarum. However, no subsequent workers ever found this species in India as the taxon is endemic to the Madeira Islands, which is one of the largest group of five small volcanic islands lying in the Atlantic Ocean $560 \mathrm{~km}$ off the northwest African coast (Sequiera et al., 2010). Fernades (2011) considered it as a critically endangered species. He pointed out that it is found only in two localities, one in Funchal and the other in Ribeira Brava in Madeira, Portugal. However, it is cultivated in some tropical countries, including India, for its fragrant flowers. The exact date of introduction to India is not known, but given its restricted distribution, the introduction is probably recent.

Jasminum flexile was described by Martin Vahl, based on the collection of Johann Gerhard Koenig from Western India in 1794. The species is known from southwestern China, India, Sri Lanka, northern Thailand, and Myanmar (Burma). The taxonomic confusion of $J$. flexile and $J$. azoricum in India started with Mohanan (1985), who merged J. flexile into $J$. azoricum. Since then, all the latter workers have followed this opinion. Green
(2003) treated them as distinct species but is silent on the occurrence of J. azoricum in India. Jasminum azoricum is distinguished from $J$. flexile by the shorter leaves devoid of acrodomatia, presence of seven or eight corolla lobes, and a shorter corolla tube $(1-1.5 \mathrm{~cm}$ long) whereas the leaves of J. flexile are of a larger size with prominent acrodomatia in the axils of the veins, five or six corolla lobes, and a longer $(2-3 \mathrm{~cm})$ corolla tube. The calyx lobes of $J$. azoricum are $0.5-1 \mathrm{~mm}$ long while those of J. flexile are no more than $0.25 \mathrm{~mm}$ long. These characters warrant of its taxonomic status as a distinct species.

Since both species are found in southern India, it is important to provide a note on their occurrence and identity to facilitate their identification. Both are described and illustrated here.

Jasminum azoricum L., 1753 (Fig. 1)

Linnaeus, C., Species Plantarum, 7 (1753).

Specimens examined: TBGT 57287; Chirayinkeezhu, Thiruvananthapuram district, Kerala, India, 20 Feb 2005, A. Sabeena. TBGT 57714; Venjaramoodu, Thiruvananthapuram district, Kerala, India, 20 Apr 2005, A. Sabeena.

Climbing shrubs; stems smooth, rounded, glabrous. Leaves trifoliolate, opposite, glabrous, subcoriaceous; petiole to $2.5 \mathrm{~cm}$ long; leaflets ovate-lanceolate, acute or shortly cuneate at base, acuminate at apex, entire at margin; venation more or less reticulate, with 5-7 primary veins per side, shallowly impressed above, linked into a submarginal vein, acrodomatia absent; terminal leaflet 2.5-7 $\mathrm{x} 1-3 \mathrm{~cm}$ on a petiolule $0.2-1 \mathrm{~cm}$ long. Flowers in axillary or terminal, 10-18 flowered, paniculate cymes, 6-12 cm long; pedicel (0-) 2-4 mm long; bracts subulate, $0.3-$ $0.6 \mathrm{~mm}$ long, minutely hairy. Calyx tube 3-4 $\mathrm{mm}$ long, minutely hairy or glabrous; lobes 5 , 
shallowly triangular, $1 \mathrm{~mm}$ long. Corolla salverform, white, fragrant; tube $1.5-2.2 \mathrm{~cm}$ long; lobes 7-8, 1-1.2 x 0.3-0.5 cm long, elliptic, acute at apex. Anthers 2, to $4 \mathrm{~mm}$ long, shortly apiculate, glabrous; filament 1 mm long. Ovary bilocular; ovule 1 in each cell; style up to $1.7 \mathrm{~cm}$ long; stigma shortly bifid. Fruits not seen.

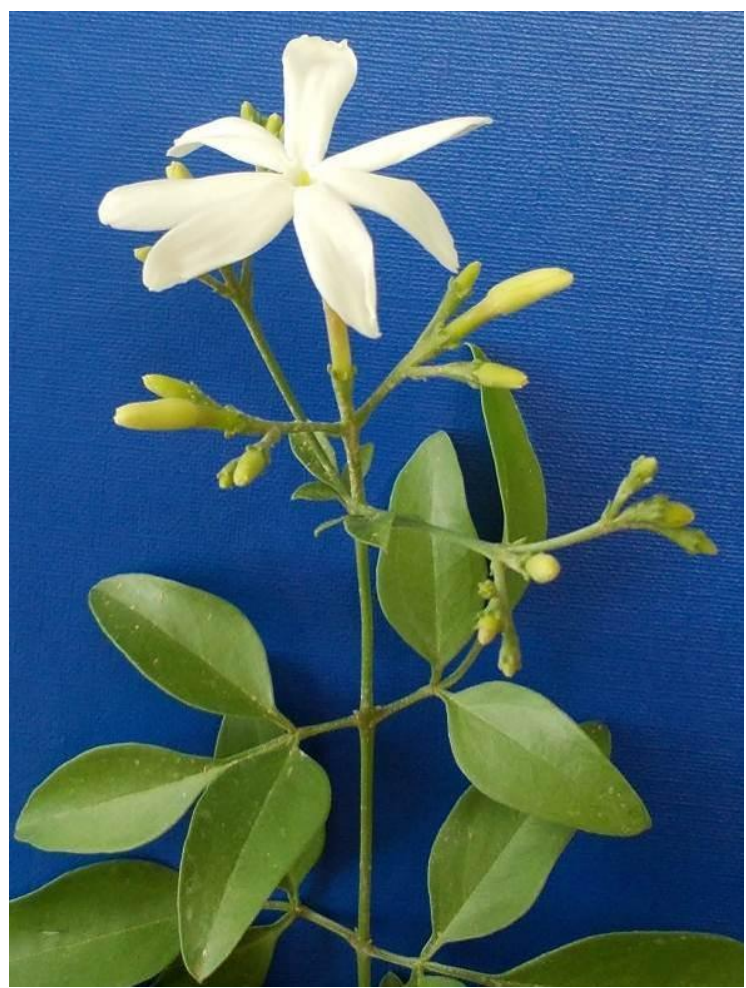

Figure 1: An inflorescence of Jasminum azoricum

Flowering and fruiting: Throughout the year.

Distribution: Endemic to Madeira Islands, though widely cultivated in the tropics for its fragrant flowers.

Habitat: Cultivated in homes and public gardens, often found wild near areas of habitation.

Clarke (1882) treated Jasminum flexile with three varieties, viz., var. flexile, var. hookeriana C. B. Clarke, and var. ovatum C. B. Clarke from what was then British India. Of these, Peninsular India harbours only var. ovatum and var. flexile. According to Clarke (1882), J. flexile included $J$. acuminatum B. Heyne ex Wall., J. azoricum L., and J. travancorense B. Heyne ex Wall. However, Gamble (1923) segregated $J$. travancorense as var. travancorense. $\mathrm{He}$ distinguished var travancorense by the "...terminal leaflets not truncate at base, rounded or obtuse, leaflets elliptic-oblong, lateral nerves 8 pairs, more prominent and prominently arching,...". The figure provided by Wight (1848: 4, t. 1253) probably represented var. travancorense. In India, it is found in low altitude evergreen and semi-evergreen forests of southern India whereas var. flexile is found in the high altitude mountains of Nilgiris.

Green (2003) has a broad species concept, accommodating all varieties under Jasminum flexile. Detailed studies of both herbarium and live plants convinced us to retain var. ovatum rather than assign it to synonymy under var. flexile. The var. ovatum can be distinguished from its allies by the elliptic or elliptic-obovate leaves with prominently reticulate and arched secondary nerves, distinctly shorter petiolules in the laterals leaflets, and the much shorter inflorescence.

\section{Key to the varieties of J. flexile in Peninsular India:}

1a. Leaves always trifoliolate, never unifoliolate by reduction of lateral leaflets 2

1b. Leaves trifoliolate, occasionally unifoliolate by the reduction of two lateral leaflets

J. flexile var. ovatum

2a. Terminal leaflets elliptic or ovate J. flexile var. flexile

2b. Terminal leaflets obovate

J. flexile var. travancorense

\section{Jasminum flexile Vahl var. flexile}

(Fig. 2)

Vahl, M., Symbolae Botanicae, 3: 1 (1794).

Specimens examined: MH 17937; Nilgiri district, Tamil Nadu, India, Aug 1886, J.S. Gamble. MH s.n.; Sesi Ghats, Nilgiri district, Tamil Nadu, India; 17 Mar 1886, M.A. Lawson. MH 357; Pulney, Periya Sholai, Tamil Nadu, India; 08 Jun 1897, Bourne.

Climbing shrubs; stem rounded, glabrous. Leaves opposite, trifoliolate, membraneous, glabrous; terminal leaflets ovate-lanceolate, 7$11 \times 3.5-6 \mathrm{~cm}$, cuneate, rounded to truncate at base, acuminate and shortly mucronate at apex, entire at margins, with 3-5 pairs of veins with the basal pair of lateral veins forming a submarginal vein, acrodomatia at axils of the vein; lateral leaflets similar to the terminal but blades rarely more lanceolate, $6-8 \times 3-4 \mathrm{~cm}$; 
petioles 2-4 cm long, arcuate. Flowers borne in compound cymes, terminal on side shoots or axillary, longer than leaves, 7-15 flowered per inflorescence, white, fragrant, $2-3.5 \mathrm{~cm}$ diameter; pedicels 3-7 mm long; bracts linear, $1.5-2 \mathrm{~mm}$; peduncle $7-12 \mathrm{~cm}$ long. Calyx tube $2 \mathrm{~mm}$ long; lobes minute. Corolla white; tube 1-2.5 cm long; lobes 5, oblong, 1.2-1.5 x 0.3$0.4 \mathrm{~cm}$. Stamens 2. Berries black, ellipsoid, to $0.8 \times 0.6 \mathrm{~cm}$.

Flowering and fruiting: March-August Distribution: India, China and Sri Lanka. Habitat: Evergreen and Shola forests

\section{Jasminum flexile Vahl var. ovatum Clarke, 1882 (Fig. 3)}

Clarke, C. B. 1882. Jasminum. Pp. 601, In: J.D. Hooker (Ed.). Flora of British India, 3 (1882).

Specimens examined: TBGT 9076; Koviltherimala, Thiruvananthapuram district, Kerala, India, 21 Dec 1987, N. Mohanan. TBGT 20629; Pachallur, Thiruvananthapuram district, Kerala, India, 7 Jan 1993, V.S. Menon. TBGT 14477; Adiparambu, Thiruvananthapuram district, Kerala, India; 14 Jan. 1994, E. S. Santhosh Kumar \& M. Abdul Jabbar. TBGT 7985; Attayar, Thiruvananthapuram district, Kerala, India, 23 Dec 1985, N. Mohanan. TBGT 57293; Ponmudi, 31 Mar 2005, A. Sabeena. TBGT 2318; Low country Quilon, Kollam district, Kerala, India, 10 Jan 1914, K. Venkoba Rao.

Leaves trifoliolate or rarely unifoliolate by reduction of two laterals, subcoriaceous; terminal leaflets elliptic-obovate, $6.5-10 \times 2-4$ $\mathrm{cm}$, acute or attenuate at base, acuminate or acuminate-caudate or plicate at apex, with 6-9 pairs of lateral nerves, on a petiolule to $2.5 \mathrm{~cm}$ long; lateral leaflets ovate or ovate-lanceolate, $4-8 \times 1.3-2.5 \mathrm{~cm}$, acute or rounded at base, acuminate and apiculate at the very apex, with 5-10 pairs of lateral nerves on a petiolule to 0.4 $\mathrm{cm}$ long, glabrous. Flowers in axillary or terminal 3-5 flowered cymes; peduncle to $2 \mathrm{~cm}$ long; bracts subulate, to $0.4 \mathrm{~cm}$ long; pedicel to $5 \mathrm{~cm}$ long. Calyx cup shaped, toothed. Corolla 4-6 lobed, to $4 \mathrm{~cm}$ across; tube to $6 \mathrm{~cm}$ long; lobes $1.5-1.8 \times 0.7-0.9 \mathrm{~cm}$, elliptic-oblong. Stamens 2; anthers $0.6 \mathrm{~cm}$ long; filament to 1 $\mathrm{mm}$ long. Ovary to $1 \mathrm{~mm}$ long, glabrous; styles slender, to $2 \mathrm{~cm}$ long; stigma club shaped. Berry ellipsoid, to $1.8 \times 1.4 \mathrm{~cm}$.

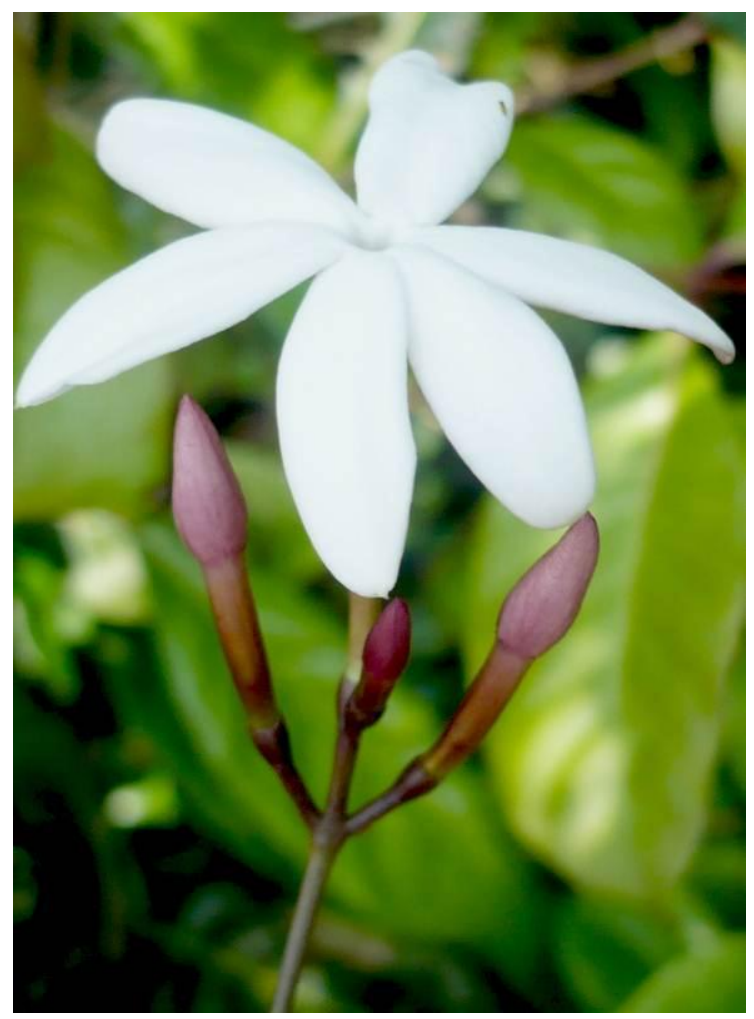

Figure 3: An inflorescence of J. flexile var. ovatum

Flowering and Fruiting: September-April Distribution: North Eastern India and Kerala. Habitat: It is found in the evergreen and semievergreen forests between 200-1000 m.

\section{Jasminum flexile Vahl var. travancorense Gamble, 1921. (Fig. 4)}

Gamble, J. S. Flora Presidency of Madras, 791 (1921)

Specimens examined: TBGT 57284; Braemore, Thiruvananthapuram district, Kerala, India, 09 Mar 2005, A Sabeena. MH 59309; Uthipanchi, Thiruvananthapuram district, Kerala, India, 20 Feb 1979, M. Mohanan. MH 51012; Ponmudi Estate, Thiruvananthapuram district, Kerala, India, 13 Sep 1977, N.C. Nair. TBGT 57286; Arippa, Kollam district, Kerala, India, 17 Feb 2005, A. Sabeena. MH 42063; Sabarimala, Pathanamthitta district, Kerala, India, 27 Sep 1972, B. D. Sharma. MH 15712; Kombar, South Canara district, Karnataka, India, 18 Dec 1918, s.coll. MH 2340; Jolpad, Karnataka, India, 13 Nov 1900, C. A. Barber. MH s.n.; Anamalai, Combatore district, Tamil Nadu, India, s. date, R. H. Beddome. MH 15698; Devala sholai, Tamil Nadu, India, Nov 1884, J.S. Gamble. MH 42864; Nadugani-Gudalur, Nilgiri district, Tamil Nadu, India, 20 Nov 1971, E. Vajravelu. 
Leaves trifoliolate, subcoriaceous; petiole 2-3 $\mathrm{cm}$ long, slightly declinate at apex; terminal leaflets 6-9 × 3-4 cm, obovate, acute at base, caudate and plicate at apex, with 5-8 pairs of lateral veins on a petiolule $0.5-1.2 \mathrm{~cm}$ long; lateral leaflets ovate, elliptic-ovate or lanceolate, $5-8 \times 1.6-3 \mathrm{~cm}$, acute at base, caudate at apex, with 7-9 pairs of lateral veins \pm prominently arched near the margin, on a petiolule to $1-2.5 \mathrm{~cm}$ long. Flowers in axillary or rarely in terminal cymes; peduncle $2-5 \mathrm{~cm}$ long, glabrous; bracts linear, $3 \mathrm{~mm}$ long, rarely forked at apex; pedicels to $1.5 \mathrm{~cm}$ long. Calyx lobes 5, triangular. Corolla $2.5 \mathrm{~cm}$ across; tube to $3 \mathrm{~cm}$ long; lobes 5, oblong, 1.2-1.5 x 0.6-0.8 $\mathrm{cm}$ long. Stamens 2; filaments to $0.5 \mathrm{~mm}$ long; anthers $2.5 \mathrm{~mm}$ long. Ovary $2.5 \mathrm{~mm}$ long; style $2.5 \mathrm{~cm}$ long, filiform; stigma linearly fusiform. Berry ellipsoid to $1.2 \times 0.7 \mathrm{~cm}$, black on drying.

Flowering and Fruiting: September-March. Distribution: Endemic to southern Western Ghats.

Habitat: It is found in the evergreen and semievergreen forests between 200-800 m.

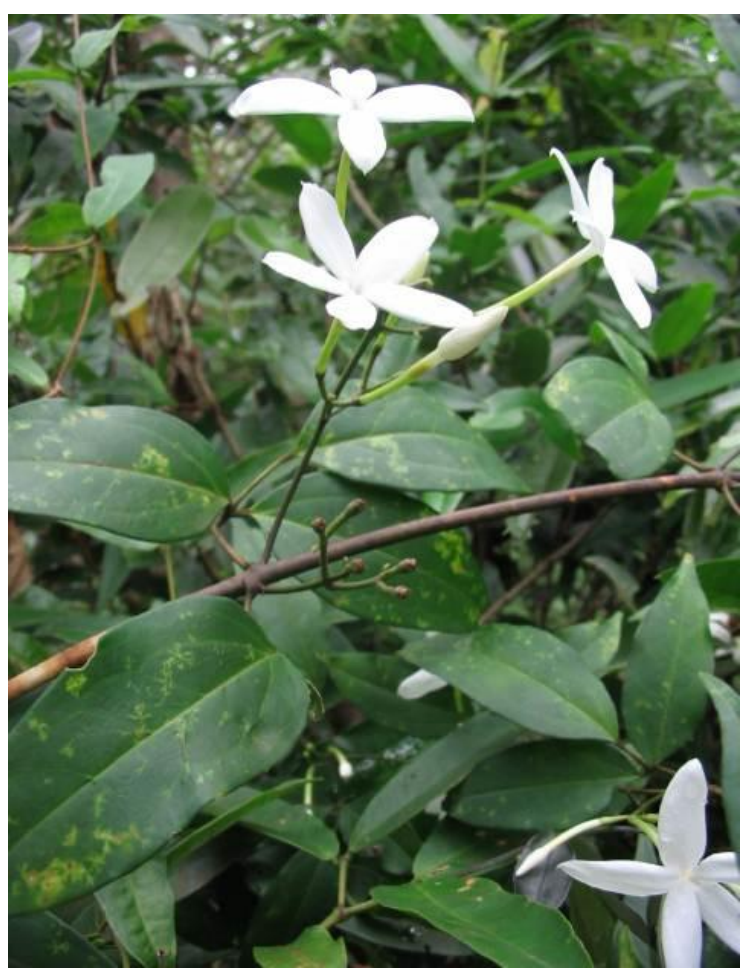

Figure 4: An inflorescence of $J$. flexile var. travancorense

\section{Acknowledgements}

The authors are grateful to the Director (JNTBGRI) for the facilities provided and the constant encouragements. They are also thankful to the Joint Director (BSI, Southern Circle, Coimbatore) for the permission to consult their herbarium and to the Curator, The Herbarium, NHM, Denmark, for granting permission to use the type image of Jasminum flexile for this publication.

\section{Literature Cited}

Clarke, C. B., 1882. Jasminum. Pp. 591-603, In: Hooker, J.D. (ed.) Flora of British India. L. Reeve \& Co., London.

Fernandes, F., 2011. Jasminum azoricum. In: IUCN 2012. IUCN Red list of threatened species. version 2012.2. <www.iucnredlist.org>. Accessed on 15 February 2013.

Gamble, J.S., 1923. Jasminum. Flora of the Presidency of Madras. Adlard \& Son, London: 785-791.

Green, P.S., 2003. Synopsis of the Oleaceae from the Indian Sub-continent. Kew Bulletin, 58: 257295.

Mohanan, M., 1985. Notes on the nomenclature of some Indian Plants. Journal of Economic \& Taxonomic Botany, 6: 480.

Sabeena, A., A. Mestry, and E.S. Santhosh Kumar, 2006. Taxonomic status of Jasminum flexile Vahl var. ovatum Clarke (Oleaceae). Journal of Economic \& Taxonomic Botany, 30: 881-884.

Sequeira, M. M., A. A. Guerra, C. E. Jarvis, A. Oberli, M. A. carine, M. Maundu, and J. F. Ortega, 2010. The Madeira Plants collected by Sir Hans Sloane in 1687, and his descriptions. Taxon, 59: 598-612.

Submitted: 13 April 2013, Accepted: 16 Nov. 2013 Sectional Editor: James L. Reveal

\section{E. S. S. Kumar ${ }^{1,2} \&$ A. Sabeena ${ }^{1}$}

\footnotetext{
${ }^{1}$ Jawaharlal Nehru Tropical Botanic Garden \& Research Institute, Palode, Thiruvananthapuram, Kerala 695562, India.

${ }^{2}$ E-mail: santhoshkumares@ gmail.com
} 


\section{PLATE 5}

IDC. microfiche foto Vahl. nr. $40 \mp, 1-2$

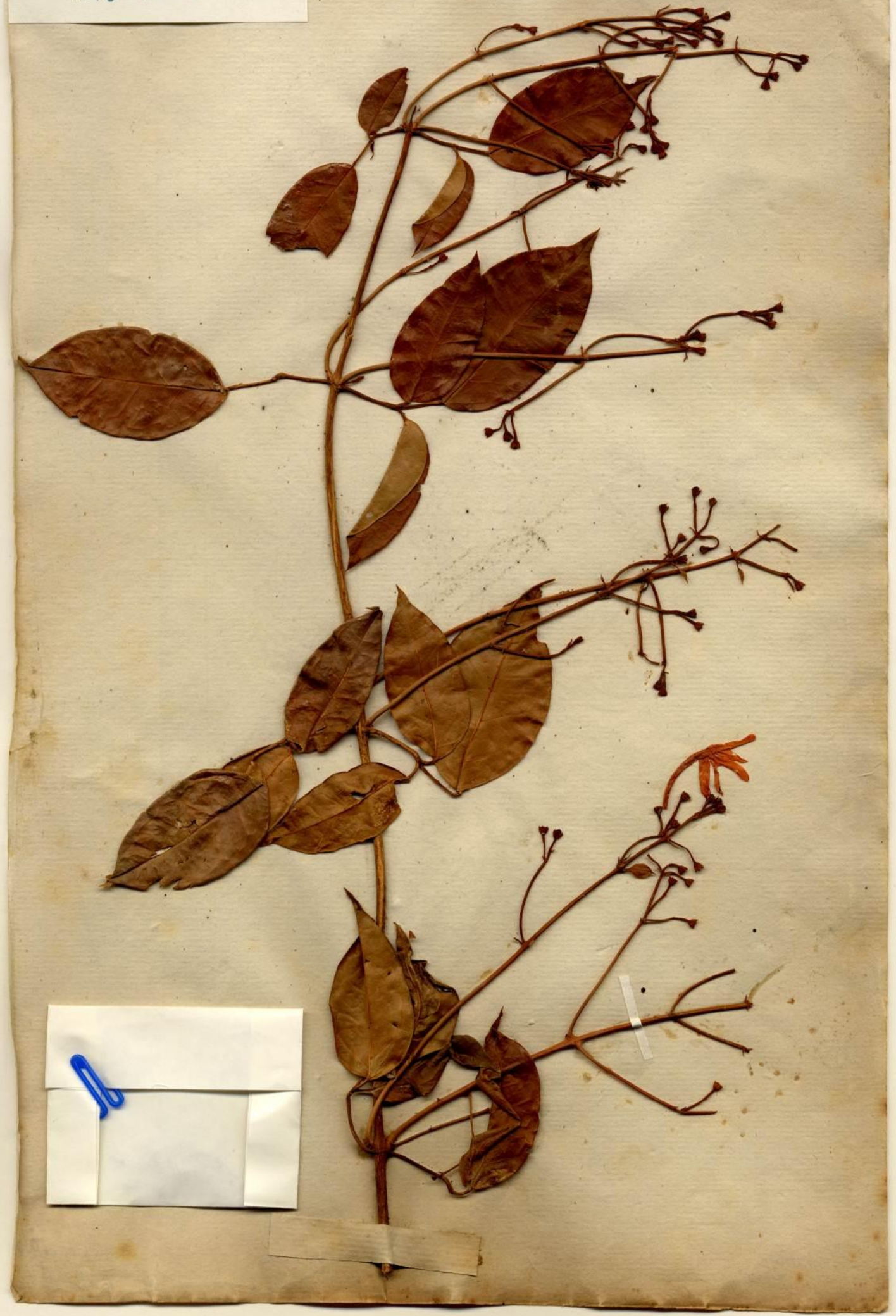

Figure 2: The type specimen of Jasminum flexile var flexile, at Copenhagen, Denmark. 